\title{
The Relationship Between Tool Use and Prey Availability in Chimpanzees (Pan troglodytes schweinfurthii) of Northern Democratic Republic of Congo
}

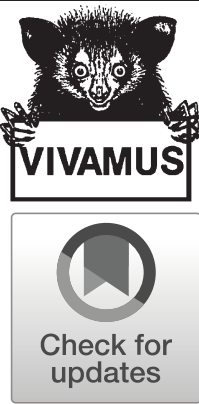

\author{
Thurston C. Hicks ${ }^{1,2}$ - Hjalmar S. Kühl ${ }^{2,3}$ - Christophe Boesch ${ }^{2}$. \\ Steph B. J. Menken ${ }^{4}$ • John Hart ${ }^{5}$. Peter Roessingh ${ }^{4}$. Corneille Ewango ${ }^{6}$. \\ Roger Mundry ${ }^{7}$
}

Received: 5 August 2019 / Accepted: 24 February 2020 / Published online: 14 May 2020

(C) The Author(s) 2020, corrected publication 2021

\begin{abstract}
A key feature of human behavioral diversity is that it can be constrained by cultural preference ("cultural override"); that is, population-specific preferences can override resource availability. Here we investigate whether a similar phenomenon can be found in one of our closest relatives, as well as the potential impacts of ecological differences on feeding behavior. Our study subjects were different subpopulations of Eastern chimpanzees (Pan troglodytes schweinfurthii) occupying two very different habitats, moist tropical lowland forests vs. moist tropical forest-savanna mosaic on opposite sides of a major river. Given differences in encounter rates of different kinds of tool sites on both sides of the Uele River, we predicted that these subpopulations would differ in their likelihood of using tools to prey on two insect species despite similar availability. In surveys conducted over a 9-year period at 19 different survey regions in northern Democratic Republic of Congo (10 in lowland forest and 9 in mosaic), we collected and analyzed data on chimpanzee tool-assisted exploitation of insects. To determine the availability of insect species eaten by the chimpanzees, we counted insects and their mounds on transects and recces at 12 of these sites. For stick tools used to harvest epigaeic Dorylus and ponerine ants, we evaluated seasonal, geographical, and prey-availability factors that might influence their occurrence, using nest encounter rate as a proxy to control for chimpanzee abundance. Across the 19 survey regions spanning both sides of the Uele, we found little difference in the availability of epigaeic Dorylus and ponerine ants. Despite this, tool encounter rates for epigaeic
\end{abstract}

\section{Handling Editor: Stacy Lindshield}

Electronic supplementary material The online version of this article (https://doi.org/10.1007/s10764-02000149-4) contains supplementary material, which is available to authorized users.

Thurston C. Hicks

clevehicks@hotmail.com

Extended author information available on the last page of the article 
Dorylus, but not ponerine, ants were significantly higher in the mosaic to the north of the Uele. Furthermore, we found no evidence for termite fishing anywhere, despite the availability of Macrotermes mounds throughout the region and the fact that chimpanzees at a number of other study sites use tools to harvest these termites. Instead, the chimpanzees of this region used a novel percussive technique to harvest two other types of termites, Cubitermes sp. and Thoracotermes macrothorax. This mismatch between prey availability and predation is consistent with cultural override, but given the different habitats on the two sides of the Uele River, we cannot fully rule out the influence of ecological factors. Comparing our findings with those of similar studies of other chimpanzee populations promises to contribute to our understanding of the evolution of behavioral diversity in humans and our closest cousins.

Keywords Cultural override · Eastern chimpanzees · Northern Democratic Republic of Congo $\cdot$ Pan troglodytes schweinfurthii

\section{Introduction}

Human behavior is characterized by its remarkable diversity in most observable domains. For instance, clothing, architecture, housing style, language, pet choice and food preference can all differ profoundly between cultures (Murdock 1981; see also Electronic Supplementary Material [ESM] 1). Much of this variation is assumed to be based on culture, defined by Whiten et al. (1999) as "behavior that is transmitted repeatedly through social or observational learning to become a population-level characteristic." Environmental factors obviously also play a part; for instance, an isolated desert society with no access to the sea cannot develop a seaweed-based cuisine. In addition, some preferences, such as milk-drinking by adults, can be linked to genetic differences between populations (lactase persistence; Krebs 2009) and to socioeconomic factors (Scholliers 2001). Nevertheless, it is clear that socially learned preferences impact which foods human cultures see as edible and/or desirable, as well as the details of their tools, housing, and clothing. This bias toward culturally approved solutions and preferences, or "cultural override," has a strong influence on human behavior (Haun et al. 2006) and could represent one of the factors that differentiate human culture from other animal traditions (i.e., learned behaviors that show continuity across generations; McGrew 2004). This raises the question of whether such a divorce between resource availability and the development of material traditions to harvest those resources can be recognized in other species, in particular in our close cousins the chimpanzees (Pan troglodytes).

Possible culturally mediated differences in food preferences and other behaviors have been proposed for a number of nonhuman primates, i.e., gorillas (Gorilla gorilla and G. beringei: Ganas et al. 2004; Ganas and Robbins 2004; Robbins et al. 2016), Bornean orangutans (Pongo pygmaeus wurmbii: Jaeggi et al. 2010), and white-faced capuchins (Cebus capucinus: Panger et al. 2002). Chimpanzees display the largest number of putative cultural variants of any nonhuman animal studied (Whiten et al. 1999), with multiple traditions identified across Africa, including subsistence-oriented 
material culture, gestural "dialects" (Luncz and Boesch 2015; Luncz et al. 2015; McGrew and Tutin 1978; Nakamura 2002), and differences in food preferences (Nishida et al. 1983), in some cases even between neighboring communities (Boesch et al. 2006; Hobaiter et al. 2017). Migrating female chimpanzees change their nutcracking techniques to match those used by their new community (Luncz et al. 2015). A similar result was obtained in captivity, where chimpanzees would replace their own technique of opening a box to match the variant technique of a group of chimpanzees, but not a single individual (Watson et al. 2018). Experiments with captive chimpanzees have further shown the apes to be capable of transmitting variants of experimentally seeded behaviors from one group to another; for reviews, see Whiten $(2017,2019)$.

The mechanisms through which cultural variants are spread and maintained in nonhuman great apes are hotly debated, with some results favoring attributes formerly considered uniquely human, such as "conformity" (apes in the minority adapting their behavior to fit into a new norm) (Whiten et al. 2005) and even, in the wild, some forms of teaching (Boesch 2012). Other researchers, however, have challenged this proposed continuity between human and chimpanzee mechanisms of cultural transmission, arguing that nonhuman great apes lack traits such as conformity (Haun et al. 2014), imitation, and cumulative culture (Marshall-Pescini and Whiten 2008b; Tennie et al. 2009), thus limiting the usefulness of cross-species comparisons [ $c f$. Sanz and Morgan (2007) for a possible example of cumulative culture in the wild, the manufacture of termite brush sticks]. Field experiments have shed some light on these issues. For instance, chimpanzee behavior, like that of humans, appears in some cases to be constrained by cultural override: (Gruber et al. 2009, 2011): i.e., different populations respond differently to environmental cues based on their adherence to local traditions, in this case leading to markedly different responses to leafy sticks as potential toolmaking material. It is unclear whether this is maintained by conformity as discussed in the preceding text or some other mechanism, but the similarity to human cultural preferences is suggestive. Nevertheless, differentiating the possible influence of cultural from genetic and ecological factors presents researchers with a formidable challenge (Langergraber et al. 2010; McGrew 1992).

\section{Competing Explanations for Chimpanzee Behavioral Diversity}

When postulating cultural explanations for behaviors in chimpanzees and even in humans, we must first rule out competing explanations (McGrew 1992, 2004). Langergraber et al. (2010) pointed out the difficulty of disentangling genetic influences on behavior from cultural ones. In addition, some examples of "cultural variation" can be explained more parsimoniously as being tied to ecological factors (Collins and McGrew 1987; Koops et al. 2013, 2014) or differences in the behavior of invertebrate prey (Möbius et al. 2008). Finally, Tennie et al. (2009) proposed that chimpanzees may be using simpler learning mechanisms for transmitting traditions than those used by humans ("zone of latent solutions" hypothesis). An important corollary of the latter hypothesis is that ecological conditions may "draw out" universal chimpanzee capabilities that are not expressed in other contexts. 
Koops et al. $(2013,2014)$ showed that "opportunity" (i.e., increased availability of a particular resource will increase the likelihood that chimpanzees will exploit it) was more important than "necessity" (a lack of alternative resources increases the likelihood that chimpanzees will exploit another) in explaining the distribution of some chimpanzee feeding behaviors. Both factors are likely, however, to influence chimpanzee behavior under different conditions [reviewed in Gruber et al. (2016); for "necessity" exerting an influence, see that article and Yamakoshi (1998)]. The importance of either in explaining the distribution of chimpanzee material culture does not, however, rule out a role for cultural override, which makes a clear testable prediction. If cultural override is indeed important in chimpanzees, we can expect to see a mismatch between the availability of resources and the use of tools for exploitation of those resources. Absence of cultural override, at least within the framework of the "opportunity" hypothesis, suggests that tool use for a resource should closely follow resource availability (to test the necessity hypothesis, we need more information, such as on availability of fruit and vertebrate prey).

In the current study we compared tool-use north and south of the Uele River in the northern Democratic Republic of Congo (DRC) and mapped that onto resource availability. The Uele River appears to be a chimpanzee barrier (Fig. 1; Hicks 2010), and there are major ecological differences on the two sides, with the north being a moist tropical forest-savanna mosaic (from here on, mosaic), while the moist tropical lowland forest (from here on, lowland forest) to the south lacks the savanna vegetation type. We focused not on these habitat-related differences but on the comparable availability of the insect prey for these two subpopulations. Observing a mismatch in the exploitation of these insects despite comparable levels of resource availability would not rule out ecological explanations (particularly relating to the necessity hypothesis) but would at least be consistent with cultural override.

Our study population is a large and continuous population of Eastern chimpanzees (Pan troglodytes schweinfurthii: Hicks et al. 2014), thus minimizing the likelihood that genetic differentiation plays a major role in behavioral differences. We base our analyses in this article on encounter rates of tools found during our large-scale survey of chimpanzee material culture (Hicks et al. 2019a), incorporating information on insect availability for key chimpanzee prey species. This study of material traditions across a large and continuous chimpanzee population allows us to document the distribution of nonhuman primate traditions across a climatically and florally heterogeneous zone following a recent evolutionary history of probably only thousands or tens of thousands of years (Hicks et al. 2019a). Investigating the impact of prey availability on chimpanzee selection of insects as food items will help us to understand the constraints (or lack thereof) on the evolution of great ape cultures. This study is important for comparing the tool-use behavior and insectivory of savanna-dwelling chimpanzees (such as inhabit the tropical forest-savanna mosaic habitat north of the Uele River) to those which inhabit the lowland forests south of the Uele.

We collected indirect data on tool-assisted predation on insects by chimpanzees at 19 survey regions covering ca. 50,000 km2 in northern DRC (Fig. 1; Hicks et al. 2019a). For 12 of these regions, we also collected data on seasonal variation in the availability of surface-swarming, or "epigaeic," Dorylus ants and ants of the subfamily Ponerinae, as well as several species of termites. 

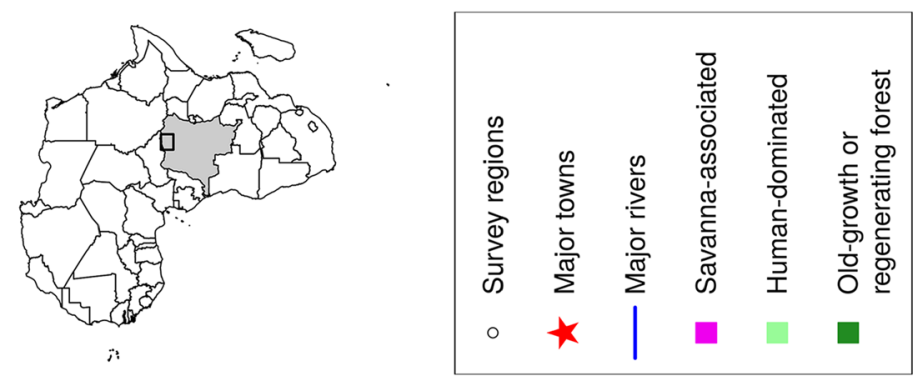

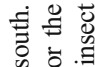

도엄

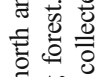

.

灵

过

这

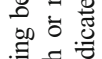

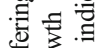

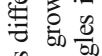

记 苞

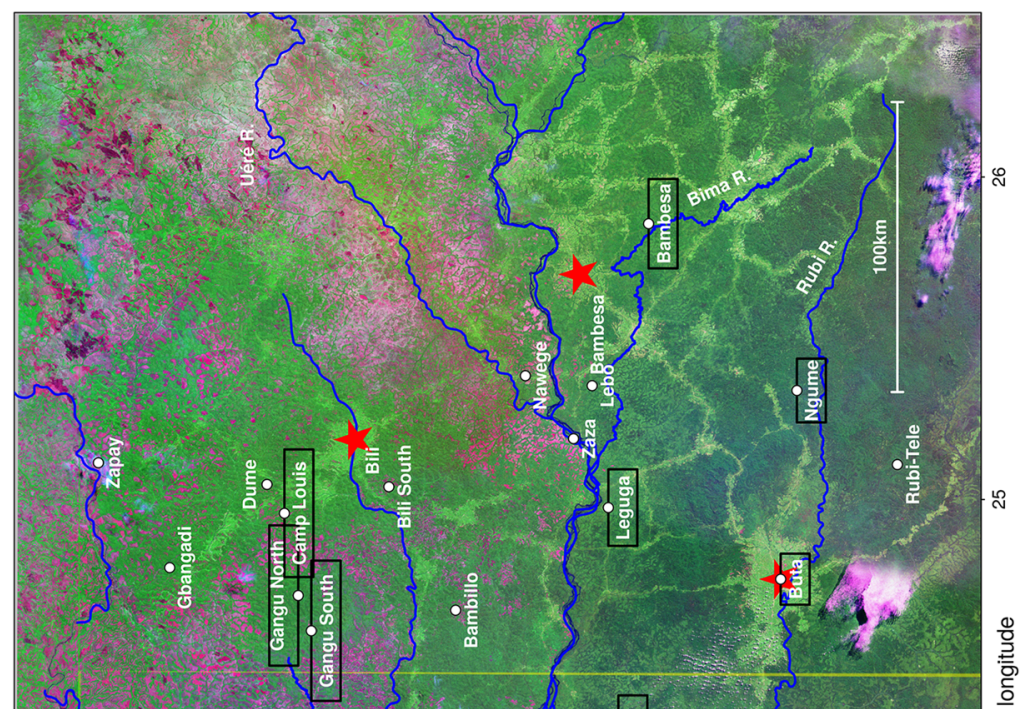

莺 专

픙

른

可 뮹

ㅎํㅇ ธू

를 을

言氞 क

से $\ddot{\otimes} \cdot \frac{0}{0}$

空

유 일

०

츠

항

즈웡

递

: 吾矛

요유

흐 है

خे

क 气 ए

플

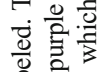

त्व

글

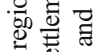

入

害芯

量告

की

윯

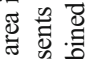

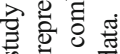

$\square$ ฮี

巨边告

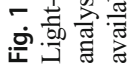




\section{Methods}

\section{Study Area}

Between 2004 and 2013, the first author (TH) conducted a study of chimpanzees at 19 localities ("survey regions") across a previously un-surveyed area of northern DRC, between the Tele River in the south and the Mbomu River in the north (ESM 2). Nine of these regions were to north of a major river, the Uele, and 10 were to its south. Climate and geography north and south of the Uele are reviewed in Hicks (2010). In general, South Uele regions are at a lower elevation than North Uele (South Uele range: 380-600 m; North Uele range: $570-700 \mathrm{~m}$ ). During the first half of the twentieth century, the mean maximum (30 vs. $30.1^{\circ} \mathrm{C}$, Bambesa South Uele vs. Tukpwo North Uele) and minimum daily temperatures (18.2 vs. $19.1^{\circ} \mathrm{C}$, Bambesa vs. Tukpwo) were comparable between north and south (Bambesa and Tukpwo data: Gérard 1960). Despite an overall similar amount of rainfall [Tukpwo, near Bili, prior to 1960: $1644 \mathrm{~mm}$ (Gérard 1960); Bambesa, South Uele, 1922-1950: $1779 \mathrm{~mm}$ (Gérard 1960); Aketi, South Uele, 2007-2008: 1652 mm (Hicks 2010)], north of the Uele the contrast between the wet and dry seasons (dry: DecemberMarch) was more extreme, with no rainfall recorded over a 4-month period for 2 consecutive seasons (2004-2005 and 2006-2007), as befits an area bordering the Sahel zone. This lack of rainfall led to forest streams, some of them $>2 \mathrm{~m}$ deep in the wet season, disappearing completely in the dry season. We did not observe such an extreme pattern in the South Uele forests.

The flora to the north of the Uele River is a vast ecotone characterized by a mosaic of primary forest, savanna woodland and open grassland which gradually becomes more arid and savanna-dominant the further north one travels. Some researchers would classify the Bili-Uéré landscape as a "forest mosaic," while others would consider it to be a savanna landscape with a relatively high proportion of forest cover (van Leeuwen et al. 2020). Approximately half of the area surveyed north of the Uele consisted of savannaassociated vegetation types (open grassland and savanna woodland, represented by purple in Fig. 1). South Uele is characterized by moist semideciduous tropical lowland forests, with a complete lack of savannas (open grassland or woodland) where we surveyed. On both sides of the Uele, numerous small streams flow across the landscape, forming gallery forests to the north. In the south (and somewhat less commonly in the north), the borders of these streams are often monodominant stands of Gilbertiodendron dewevrei (Gérard 1960; Hicks pers. obs.). Human population densities are much higher south of the Uele, leading to higher levels of artisanal mining, slash-and-burn agriculture, and hunting (Hicks et al. 2010). Along roads and near villages, natural forests have been replaced by cultivated fields, monodominant stands of oil palms, and dense regenerating forest. In certain regions south of the Uele, vast tracts of forests consist of dense herb patches containing relatively few large trees (Fig. 2; Hicks 2010; Hicks et al. 2013). 
a

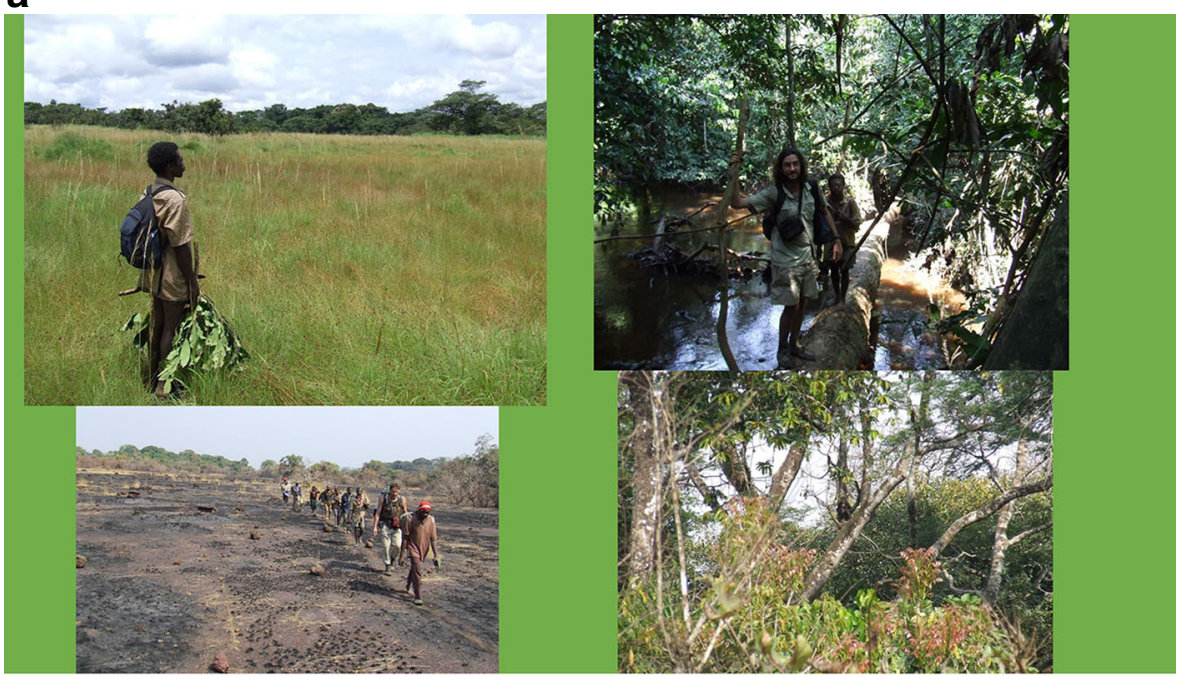

b

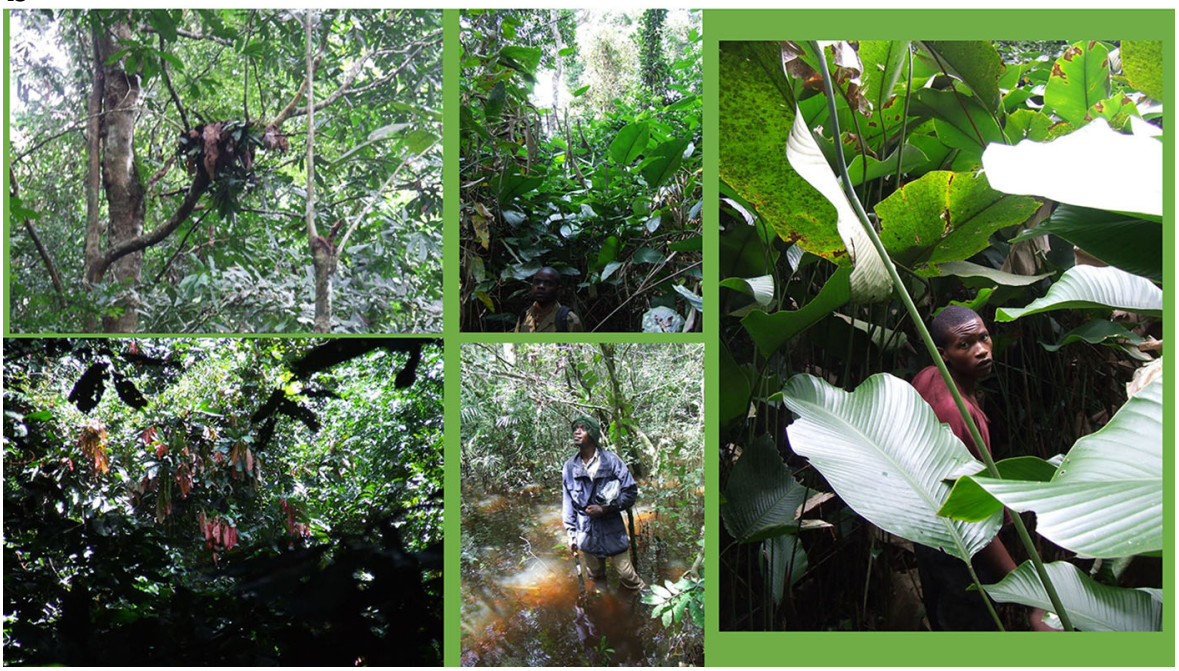

Fig. 2 (a) Vegetation types typical of North Uele, DRC (clockwise from top left): Ligada Faustin in open grassland, Bili; TH and Faustin cross a seasonally flooded stream, Gangu Forest (in the dry season, this stream vanishes; here it is $>2 \mathrm{~m}$ deep); Eastern chimpanzee (Pan troglodytes schweinfurthii) in a tree overlooking open grassland, Zapay (just south of the Central African Republic); the 2006 field team crossing seasonally burned open grassland, Bili (foreground: Mbolibie Cyprien and Jeroen Swinkels). (b) Vegetation types typical of South Uele, DRC (clockwise from top left): Chimpanzee nest in monodominant Gilbertiodendron dewevrei forest, Lebo; Olivier Esokeli in a dense tangle of herbs and vines at Mbange West; Babulu in a Marantaceae herb patch, Akuma Forest; Sebastian Koya in a swamp forest at Lingo; more Gilbertiodendron forest, Lebo.

Tree species common in the savanna woodlands and open grasslands north of the Uele include Annona senegalensis, Burkea africana, Combretum collinum, Hymenocardia acida, Parinari curatelifolia, Stereospernum kunthianum, 
Strychnos spp., and Vitex spp. (World Wildlife Fund 2007). TH's team also confirmed the presence of the genera Strychnos, Parinari, and Combretum at Bili. In the open grasslands and woodlands, common grasses are Andropogon spp., Hyparrhenia spp., and Loudetia spp. (Hicks identified Pannicum maximum, Pennisetum polystachion, and Hyparrhenia sp. at Bili). In the lowland forests typical of South Uele, common tree species are Julbernardia seretti, Cynometra alexandri, and Gilbertiodendron dewevrei (Burgess et al. 2004). For a more detailed description of the vegetation of both areas, please refer to Hicks (2010).

\section{Chimpanzees and Tools}

Despite the marked difference between habitat types to the north and south of the Uele River described in the preceding text (mosaic vs. lowland forest, respectively), Hicks et al. (2019a) describe a relatively uniform set of chimpanzee material traditions, with stick tools used to obtain five types of insects or their products, the pounding open of termite mounds and fruits, against substrates and a lack of evidence for the consumption of the widely available Macrotermes termites. This is perhaps surprising given the differences in habitat types on the two sides of the river. Unlike the bonobos studied in the similar Bolobo ecotone described by Pennec et al. (2020), the North Uele chimpanzees frequently foraged, nested, and fed in savanna woodland, although evidence of their use of open grasslands was rare (Hicks 2010). At 12 of these survey regions (3 to the north of the Uele and 9 to its south; Fig. 1; ESM 2), TH recorded, in addition to information on chimpanzee nests, tools, and other artefacts, data on the availability of several insect species that are known to be consumed by chimpanzees in northern DRC or at other chimpanzee research localities: epigaeic Dorylus (D. terrificus and D. wilverthii) and ponerine ants (mostly Megaponera analis but also Paltothyreus tarsatus, both formerly of the genus Pachycondyla) as well as termites of the genera Macrotermes, Thoracotermes, and Cubitermes (for more details of the methodology, see Hicks et al. 2019a). Following Schöning et al. (2008), we classified driver ants (Dorylus) into "epigaeic" and "intermediate" species: the epigaeic ants hunt in massive swarms on and above the ground surface, whereas intermediate ones limit their hunting to the leaf litter. The former respond aggressively to disturbance of their bivouacs or foraging trails, whereas the latter are timid, bite mildly, and generally retreat underground when disturbed. As detailed in Hicks et al. (2019a), we were easily able to distinguish the tool sites of epigaeic Dorylus and ponerine ants, even when the ants themselves were not present (Fig. 3 ). For these latter sites, we assigned resources based strictly on site characteristics such as presence of insect nests, mounds, and holes (for more details on the assignment process, please see Hicks et al. 2019a). We generally found epigaeic Dorylus bivouacs at the bases of large trees; they consisted of meters-deep cavernous holes surrounded by large earthen mounds. Ponerine mounds were much smaller, had either single holes or were peppered with several tiny ones, and we almost never found them at the bases of large trees. 

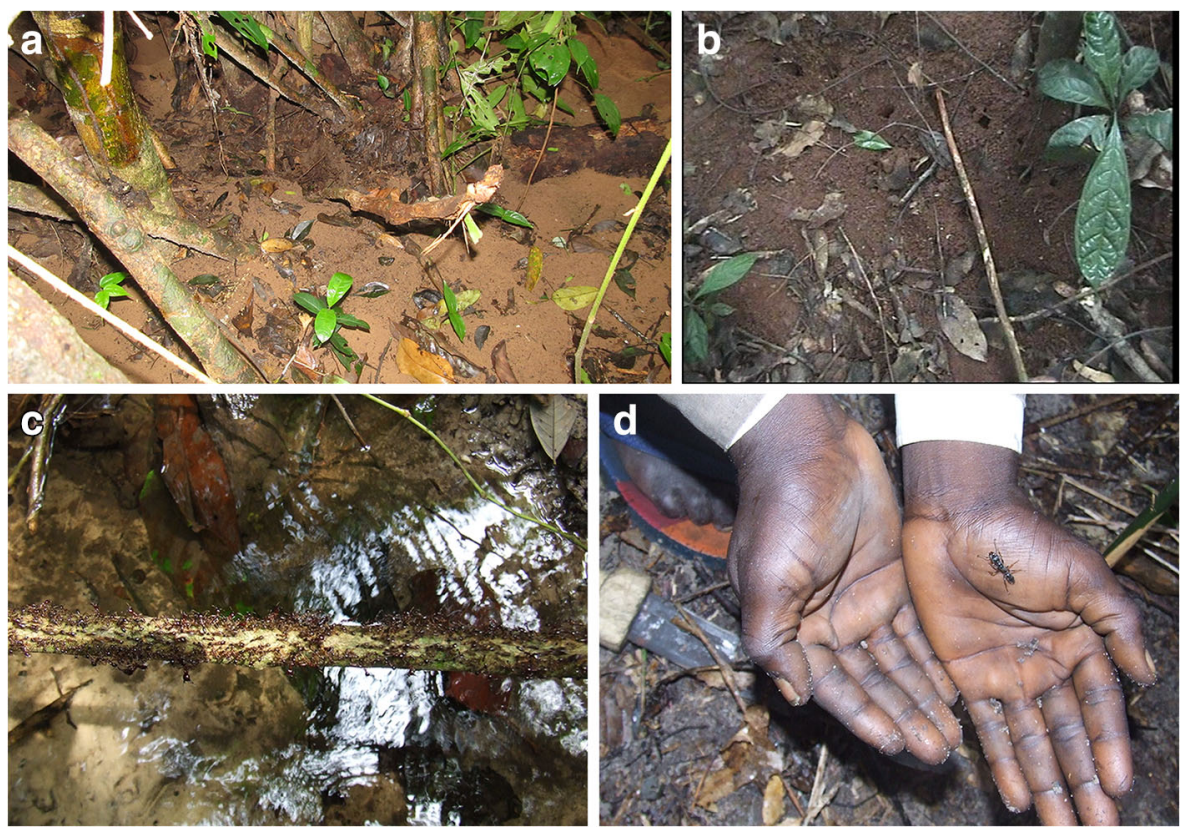

Fig. 3 (a) An epigaeic Dorylus mound with a long probe projecting from a deep hole, found in the Gangu Forest, North Uele, DRC, August 15, 2012 (photo by Gilbert Pakulu). (b) A ponerine ant tool site found in the Gangu Forest, May 30, 2005. (c) A stream of epigaeic Dorylus ants crossing a stick bridge in the Mbange Forest, South Uele, DRC. (d) A ponerine ant from a tool site in the Buta Forest, South Uele.

\section{Plant Availability for Tool Construction}

To assess possible ecological factors influencing differences in uses of tools, we examined the distribution of the plant sources that chimpanzees used to make their tools. Using data taken from Hicks et al. (2019a), as well as the results of the surveys of Gérard (1960) and the Ituri Dynamics Plots conducted by C. Ewango in RFO, Ituri Forest (see Makana et al. 2004 for details of this survey), we compiled data detailing the availability of plants used in tool construction.

\section{Statistical Analysis}

Originally, we aimed to model the extent to which insect availability explained tool use. To this end, we first modeled seasonal variation in insect availability. These models indeed revealed seasonal variation but the absolute variation was very limited. Although we found a weak trend for higher encounter rates of epigaeic Dorylus to the north, the differences in encounter rates between ponerine and epigaeic Dorylus to the north vs. south of the Uele River were not significant (ESM 3). Hence, we decided to not account for insect availability in the models of tool use. For details of the methods and results of models of insect availability, see ESM 3. 
We compared encounter rates of Dorylus and ponerine tool sites, respectively, north and south of the Uele using generalized linear models (McCullagh and Nelder 1998) with a negative binomial (Dorylus) or Poisson error distribution (ponerine) and a log link function (i.e., there was only one key predictor in the model, namely the factor "location," with levels "North Uele" and "South Uele"). We initially accounted for spatial autocorrelation in both models, but since it appeared negative in the Dorylus model we removed it from that model. To account for the varying sampling effort, we included the number of kilometers (log transformed) walked per site as an offset term. To account for variation in chimpanzee densities between survey sites, we included as a proxy for chimpanzee abundance an additional offset term the (log transformed) number of nests per kilometer walked (McCullagh and Nelder 1998). Sample size for both models was 19 sites, and none of them was overdispersed (dispersion parameters, Dorylus: 1.093; ponerine: 0.552 ). We evaluated model stability by means of DFBeta values (Field 2005). We fitted the models in R (version 3.4.4; R Core Team 2018) using the functions glm.nb of the package MASS (version 7.3-50; Venables and Ripley 2002) or glm.

\section{Ethical Note}

We report that no conflicts of interest exist in the publication of this article. The Congolese field assistants depicted in Fig. 2 worked as guides for our research project and gave $\mathrm{TH}$ verbal consent to use their photographs in published articles. The collection of the abundant and widely distributed driver ant and ponerine species was in accordance with the research permit granted by the Congolese Ministry of Environment.

Data Availability Most of the datasets used in our analyses can be found in the Supplementary Materials (see Table SIIA, Table SIIB, Table SIII). Any other data used for analysis in the current study are available from the corresponding author on reasonable request.

\section{Results}

\section{Tool Use and Insect Availability}

We found epigaeic Dorylus and ponerine ants on both sites of the Uele River. We also documented epigaeic Dorylus and ponerine ant tools and tool sites north and south of the Uele (Table I). For epigaeic Dorylus ants, tool site encounter rates were significantly higher north of the Uele River, and the chimpanzees used a long tool type not found to the south (Table II; Fig. 4a). These "long ant probes," described in detail in Hicks et al. (2019a), could reach $2.45 \mathrm{~m}$ in length, and had a mean length of $1.2 \mathrm{~m}$; thus they are the longest tools known so far to be used by chimpanzees to prey on insects in Africa. To the south of the Uele, we found only one epigaeic Dorylus tool site, and the two tools there were short (74.5 and 63.1 
Table I Epigaeic (Ep.) Dorylus and ponerine ant tools and tool sites per km walked in 9 North Uele and 10 South Uele survey regions in DRC, 2004-2013

\begin{tabular}{|c|c|c|c|c|c|c|c|c|}
\hline Area & Region & $\begin{array}{l}\text { Km } \\
\text { walked, } \\
\text { tool } \\
\text { survey }\end{array}$ & $\begin{array}{l}\text { Ep. } \\
\text { Dorylus } \\
\text { tool sites }\end{array}$ & $\begin{array}{l}\text { Ep. } \\
\text { Dorylus } \\
\text { tools }\end{array}$ & $\begin{array}{l}\text { Ponerine } \\
\text { tool sites }\end{array}$ & $\begin{array}{l}\text { Ponerine } \\
\text { tools }\end{array}$ & $\begin{array}{l}\mathrm{km} \\
\text { walked, } \\
\text { tree nest } \\
\text { survey }\end{array}$ & $\begin{array}{l}\text { Tree nests, } \\
N \text { and } \\
\text { encounter } \\
\text { rate ( ) }\end{array}$ \\
\hline \multirow{10}{*}{$\begin{array}{c}\text { North of } \\
\text { Uele }\end{array}$} & Camp Louis & 1430.6 & 9 & 26 & 1 & 1 & 1178.9 & $347(0.29)$ \\
\hline & Gangu N & 813.5 & 3 & 13 & 3 & 15 & 508.5 & $574(1.12)$ \\
\hline & Gangu S & 135.9 & 3 & 14 & 0 & 0 & 93.6 & $85(0.91)$ \\
\hline & Dume & 93.6 & 0 & 0 & 0 & 0 & 66.6 & $14(0.21)$ \\
\hline & Zapay & 49.9 & 2 & 14 & 1 & 2 & 49.9 & $118(2.37)$ \\
\hline & Gbangadi & 31.7 & 0 & 0 & 0 & 0 & 31.7 & $95(3.00)$ \\
\hline & Bili South & 205 & 1 & 3 & 0 & 0 & 205 & $109(0.53)$ \\
\hline & Nawege-Zaza & 21.7 & 0 & 0 & 0 & 0 & 13.8 & $32(2.32)$ \\
\hline & Bambillo & 76.2 & 4 & 16 & 0 & 0 & 59.7 & $43(0.72)$ \\
\hline & Total & 2858 & 22 & 86 & 5 & 18 & 2207.7 & $\begin{array}{r}1417 \\
(0.64)\end{array}$ \\
\hline \multirow{11}{*}{$\begin{array}{l}\text { South of } \\
\text { Uele }\end{array}$} & Lebo & 41.3 & 0 & 0 & 3 & 8 & 41.3 & $159(3.85)$ \\
\hline & Lingo & 38.5 & 0 & 0 & 0 & 0 & 38.5 & $40(1.04)$ \\
\hline & Zongia & 35.7 & 0 & 0 & 0 & 0 & 35.7 & $28(0.78)$ \\
\hline & Mbange East & 80.9 & 0 & 0 & 0 & 0 & 80.9 & $91(1.13)$ \\
\hline & Mbange West & 45.5 & 0 & 0 & 0 & 0 & 45.5 & $70(1.54)$ \\
\hline & Leguga & 48.5 & 1 & 2 & 1 & 3 & 43.7 & $81(1.85)$ \\
\hline & Bambesa & 65 & 0 & 0 & 2 & 2 & 65 & $190(2.92)$ \\
\hline & Akuma-Yoko & 22.4 & 0 & 0 & 0 & 0 & 22.4 & $35(1.56)$ \\
\hline & Buta & 25.6 & 0 & 0 & 2 & 3 & 25.6 & $39(1.52)$ \\
\hline & Ngume & 37.5 & 0 & 0 & 2 & 2 & 37.5 & $28(0.75)$ \\
\hline & Total & 441 & 1 & 2 & 10 & 18 & 436.1 & 761 (1.73) \\
\hline
\end{tabular}

We also include tree nests encountered per $\mathrm{km}$ of forest walks. Figure 4 provides encounter rates for tool sites and tools.

Data sources: Tool sites: Hicks et al. (2019a). Tree nest encounter rates: (recces) Hicks et al. (2014); (transects) Hicks (2014).

$\mathrm{cm})$. For ponerine ants, we found no significant difference between tool site encounter rates north and south of the Uele (Table III; Fig. 4b).

\section{Plant Species Availability for Tool Construction}

A considerable fraction of the plant species used for making tools north of the Uele River were also present to the south of it. Many of these plants are widespread across northern DRC (Table IV; ESM 4). In the Discussion, we will refer to this table to address whether availability of these species may differentially influence the use of tools by chimpanzees to prey on epigaeic Dorylus to the north and south of the Uele River. 
Table II Results of a model comparing encounter rates with Dorylus tool sites used by chimpanzees north and south of the Uele River, DRC, 2004-2013

\begin{tabular}{lllllllll}
\hline Term & Estimate & SE & Lower Cl & Upper Cl & $z$ & $P$ & Min $^{\mathrm{a}}$ & Max $^{\mathrm{a}}$ \\
\hline Intercept & -4.150 & 0.366 & -4.881 & -3.396 & & $-\mathrm{b}$ & -4.440 & -3.959 \\
N_S_Uelec & -2.488 & 1.098 & -5.461 & -0.676 & -2.265 & 0.023 & -2.928 & -1.901 \\
\hline
\end{tabular}

${ }^{a}$ Minimum and maximum of model estimates after case-wise exclusion of data points.

b Not shown because of having a very limited interpretation.

${ }^{c}$ Dummy coded with North being the reference category.

Table III Results of a model comparing encounter rates with ponerine tool sites used by chimpanzees north and south of the Uele River, DRC, 2004-2013

\begin{tabular}{lllllllll}
\hline Term & Estimate & SE & Lower Cl & Upper Cl & $z$ & $P$ & Mina $^{\mathrm{a}}$ & Max $^{\mathrm{a}}$ \\
\hline Intercept & -5.591 & 0.462 & -6.639 & -4.791 & & $-\mathrm{b}$ & -5.778 & -5.251 \\
N_S_Uele $^{\mathrm{c}}$ & 0.965 & 0.653 & -0.352 & 2.275 & 1.478 & 0.139 & 0.692 & 1.325 \\
Autocorr $^{\mathrm{d}}$ & 0.941 & 0.370 & 0.250 & 1.706 & 2.543 & 0.011 & 0.754 & 1.058 \\
\hline
\end{tabular}

${ }^{a}$ Minimum and maximum of model estimates after case-wise exclusion of data points.

${ }^{b}$ Not shown because of having a very limited interpretation.

${ }^{c}$ Dummy coded with North being the reference category.

$\mathrm{d}$ Term accounting for spatial autocorrelation.
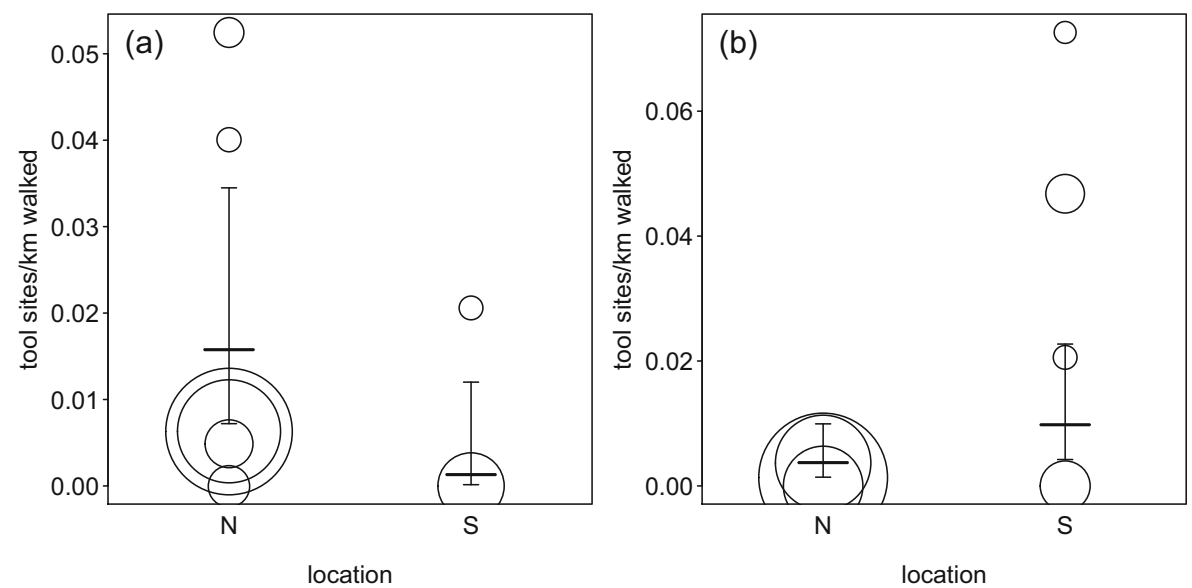

Fig. 4 Encounter rates of epigaeic Dorylus (a) and ponerine (b) tool sites to the north and south of the Uele River, DRC (2004-2013). The horizontal lines show the fitted model and the error bars its confidence intervals. The area of the circles depicts the survey effort per survey region and number of tool sites encountered (range: a: 48-1431 km walked; b: 41-1480 km walked). 
Table IV Types of plants used by Bili-Uéré chimpanzees to make epigaeic Dorylus tools (2004-2013), mostly in North Uele, DRC, limited to those we could identify to the species, and their availability across 12 sites in the Bambesa/Buta/Rubi landscape (Gérard 1960) of the South Uele as well as RFO, Ituri Forest

\begin{tabular}{|c|c|c|c|c|c|c|c|}
\hline \multirow[b]{2}{*}{ Plant species } & \multicolumn{2}{|c|}{$\begin{array}{l}\text { Epigaeic Dorylus } \\
\text { tool sources (all } \\
\text { North Uele) }\end{array}$} & \multicolumn{4}{|c|}{ South Uele (Bambesa and environs) } & \multirow[b]{2}{*}{$\begin{array}{l}\text { Ituri } \\
\text { (RFO) }\end{array}$} \\
\hline & $\begin{array}{l}\text { No. } \\
\text { tools }\end{array}$ & $\begin{array}{l}\% \text { of } \\
54 \text { tools }\end{array}$ & $\begin{array}{l}\text { Gilbertiodendron/ } \\
\text { Julbernardia } \\
\text { forests }\end{array}$ & $\begin{array}{l}\text { No. Gilbertiodendron/ } \\
\text { Julbernardia sites } \\
\text { present (out of 12) }\end{array}$ & $\begin{array}{l}\text { Other } \\
\text { forest } \\
\text { types }\end{array}$ & $\begin{array}{l}\text { All } \\
\text { combined }\end{array}$ & \\
\hline Aidia micrantha & 1 & 1.9 & + & 8 & 0 & + & $+{ }^{a}$ \\
\hline Aulacocalyx jasminiflora & 4 & 7.4 & + & 12 & + & + & + \\
\hline Blighia welwitschia & 1 & 1.9 & + & 8 & + & + & + \\
\hline Caloncoba glauca & 1 & 1.9 & 0 & 0 & + & + & + \\
\hline Celtis philippensis & 1 & 1.9 & 0 & 0 & 0 & 0 & + \\
\hline Cola urceolata & 5 & 9.3 & 0 & 0 & 0 & 0 & + \\
\hline Combretum mucronatum & 2 & 3.7 & 0 & 0 & 0 & 0 & + \\
\hline Diospyros iturensis & 1 & 1.9 & 0 & 0 & 0 & 0 & + \\
\hline Ochtocosmus africana & 1 & 1.9 & 0 & 0 & 0 & 0 & + \\
\hline Paramacrolobium coeruleum & 2 & 3.7 & + & 4 & + & + & 0 \\
\hline Rauvolfia mannii & 2 & 3.7 & + & 5 & 0 & + & $+{ }^{b}$ \\
\hline Rinorea claessensii & 6 & 11.1 & 0 & 0 & 0 & 0 & $0^{\mathrm{c}}$ \\
\hline Rothmannia urcelliformis & 2 & 3.7 & + & 3 & 0 & + & + \\
\hline Rothmannia whitfieldii & 2 & 3.7 & + & 11 & 0 & + & + \\
\hline Scottellia klaineana & 1 & 1.9 & 0 & 0 & 0 & 0 & + \\
\hline Trichilia rubescens & 2 & 3.7 & + & 6 & + & + & + \\
\hline
\end{tabular}

Ituri Dynamics Plots conducted by C. Ewango: see Makana et al. (2004). We include only those plants known to be used by the northern DRC chimpanzees to construct tools to prey on epigaeic Dorylus ants, given that it is the difference in this behavior north vs. south of the Uele River that needs to be explained. Percentages represent the proportion of tools among those for which plant species were identified via a local or Latin name, or genus $(N=54)$. $+=$ present. See ESM 4 for a more general list of plant types, which includes plants identified only to the genus.

a Common.

b Present in the understory in many places.

c On Epulu River islands only, not recorded in forest.

\section{Discussion}

Despite a relatively uniform availability of epigaeic Dorylus ants across our survey area, we found a significant difference in encounter rates of epigaeic Dorylus tool sites to the north vs. to the south of the Uele River. This was not the case with ponerine tool site encounter rates. We found tools for epigaeic Dorylus at only 1 of the 10 South Uele survey regions, but at 6 of the 9 North Uele sites (Table I). In addition, we found no long epigaeic Dorylus probes (Hicks et al. 2019a) south of the Uele River, where all of the tools were short. In terms of plant resource availability for use in tool-making, the four survey regions at which we found no tools at all (Hicks et al. 2019b) were located in dense lowland forest, which offered abundant saplings and trees, whereas in 
grassland and savanna-woodland dominated Zapay and Gbangadi we found some of the highest tool encounter rates. Despite the robust difference in epigaeic Dorylus tool encounter rates on the two sides of the river, we must remain cautious in our interpretation, as a weak trend existed for higher encounter rates of epigaeic Dorylus ants to the north of the Uele River; thus we cannot completely rule out that the chimpanzees there may have an increased opportunity to prey on this species.

Environmental conditions may also have an effect on the preservation of primate material culture (Falótico et al. 2017; Ndiaye et al. 2018; Stewart 2011). We cannot entirely rule out the potential confound that stick tools may have different decay rates based on either location (i.e., north vs. south of the Uele River, two areas characterized by major ecological differences) or season (whether we conducted our surveys in the wet vs. dry seasons). Of the 239 stick tools described in Hicks et al. (2019a) that were used to prey on all species of insects or their products, however, the encounter rate was nearly identical to the north and south of the Uele River [North Uele: 211 stick tools on $2858.1 \mathrm{~km}$ of surveys ( 0.07 per $\mathrm{km})$; South Uele: 28 tools on $440.8 \mathrm{~km}$ of surveys $(0.06$ per $\mathrm{km}$ ); see Additional Data of that paper]. In addition, a difference in decay rates of sticks between the north and south would not account for the fact that more ponerine tools were found to the north than to the south (although the difference was not significant), vs. the opposite pattern for Dorylus tools. Although population densities of chimpanzees may be higher to the south than to the north (Hicks et al. 2014), which could affect the tool encounter rates, this also would fail to account for the pattern we observed. Finally, 19 of the 27 South Uele stick tools for which age was recorded (70\%) were fresh or recent, compared to 69\% (89 of 130) of the presumed ant tools north of the Uele, indicating a similar decay rate on both sides of the river (Hicks unpubl. data). Thus it is unlikely that the different predominant habitat types of these two areas led to a higher probability of tools being found in one area than the other.

As we walked somewhat different proportions of survey lengths north and south of the Uele River in the dry and wet seasons (North Uele dry season: 613.8 of $2858 \mathrm{~km}$ walked, or $22 \%$; South Uele dry season: 174.9 of $440.8 \mathrm{~km}$ walked, or $40 \%$ ), we cannot rule out seasonality as a factor contributing to differences in encounter rates with the different kinds of tools [see Additional Data 1 in Hicks et al. (2019b)]. The encounter rate of tools in the south during the dry season/total tools was higher than that to the north: North tools dry season/total tools: 35 out of 211 tools, or $16.6 \%$; South tools dry season/total tools: 8 out of 28 , or $28.6 \%$ (Hicks et al. 2019a). Unfortunately, we could not incorporate seasonality of the tools found into our model as we did for insect availability. Because tools may survive for months after being used, it was impossible to determine during which season many of the tools had been made. Nevertheless, given the overall similarity of tool encounter rates to the north and south of the Uele, we consider seasonality to be an unlikely explanation for our findings. This is supported by the fact that we were equally likely to find ponerine tool sites, unlike epigaeic Dorylus ones, in the two areas.

Differences in vegetation types for ponerine vs. epigaeic Dorylus tools may have had some impact on preservability of, or likelihood of finding, these tools. Although we found the majority of both tool types in mixed forest, there were some differences: in the north, epigaeic Dorylus tool sites but not ponerine ones were often associated with savanna woodland or within a few meters of open grassland (20\% of sites); we were more likely to find ponerine ant tools than Dorylus ones in Gilbertiodendron dewevrei 
forest (7\% of sites) or herb patches (17\% sites) (Hicks et al. 2019a). We found epigaeic Dorylus tools more frequently in medium-density forest. Nevertheless, we found the majority of both tool types in mixed forest; thus it is unlikely that differences in habitat type north vs. south of the Uele can explain the almost complete absence of epigaeic Dorylus tools to the south, nor the extreme length of the northern tools. Although the observed patterns of resource use are at least consistent with cultural override (Gruber et al. 2009), our lack of comparable ecological data between northern DRC and other chimpanzee sites in Africa means that we cannot rule out the influence of particular ecological characteristics unique to northern DRC.

Ponerine ants are common across Africa but, based on years of study at numerous sites, chimpanzees very rarely consume them with or without tools (reviewed in Hicks et al. 2019a). These insects were nevertheless frequently preyed upon using tools by the chimpanzees across our study area.

The predominant habitat types differed considerably north and south of the Uele River (mosaic vs. lowland forest), and yet chimpanzees consumed ponerine ants across the study area. Ponerine ants themselves did not appear to be particularly abundant at Bili, compared to Gombe, where these ants are not consumed (Hicks et al. 2019a).

Langergraber et al. (2010) highlighted the difficulty of disentangling genetic influences on behavior from cultural ones [ $c f$. Marshall-Pescini and Whiten (2008a), who documented the learning of nut-cracking behavior by Eastern chimpanzees in a sanctuary, for a way forward], and such influences cannot easily be ruled out. As is the case with humans, purely genetic explanations for behavioral variation between populations are perhaps unlikely in a species such as chimpanzees with their long lives, complex behavior, and heavy dependence on social learning (McGrew 2004). In addition, the interconnectivity (and thus likely genetic homogeneity) of our study population [see Hicks et al. (2014) for the argument that the South and North Uele chimpanzees are likely connected as a population in a belt around the Uele River until it thins and disappears to the east], as well as the relatively recent divergence of all Eastern chimpanzees from an ancestral population (Fünfstück et al. 2015; Gagneux et al. 2001) make it extremely unlikely that genetic differences between subpopulations in northern DRC explain our findings.

Although it is unlikely that the availability of the food resource itself, epigaeic Dorylus ants, explains the difference in both likelihood of tool use and the lengths of the tools used to prey upon the ants, other subtle ecological or prey behavior differences between the north and south of the Uele River are much more difficult to rule out and prevent us from reaching strong conclusions. As an example of the complexity of ecological factors, a lack of availability of sodium from decaying logs may push chimpanzees in some forests to dip for driver ants for their salt content (R. Wrangham pers. comm.). Koops et al. (2019) propose that the reason that chimpanzees at Seringbara, Guinea, eat fewer driver ants when they have access to crabs is that the crabs present an alternative source of sodium. As another example, red colobus monkeys (Piliocolobus spp.), the preferred primate prey of chimpanzees across Africa (reviewed in McGrew 2004), are absent from North Uele but present to the south (Hicks et al. 2019b). Although the North Uele chimpanzees consume animal protein, perhaps the lack of red colobus leads them to consume more epigaeic Dorylus ants than their conspecifics to the south (other 
populations of chimpanzees, however, such as at Gombe, both hunt for red colobus and use tools to prey on driver ants). The ease of coming up with such possibilities demonstrates how difficult it is to exclude subtle ecological factors as drivers of behaviors. Here we will address several other possible confounds that may influence our conclusions, including variation in insect behavior or edibility, ecological and climatic factors, and plant availability.

\section{Insect Behavior or Edibility}

Differences in the behavior or edibility of the insect species themselves between the north and south of the Uele might explain our findings. Möbius et al. (2008), for instance, found that interpopulation differences in driver ant behavior contributed to differences in the tools used by chimpanzees to prey upon them (Möbius et al. 2008). Perhaps, in a similar manner, there is something different about the behavior of the epigaeic Dorylus ants to the north of the Uele River that requires the chimpanzees to use long tools to catch them, thus explaining our findings. Both epigaeic species D. wilverthii and D. terrificus are present on both sides of the Uele River, and the chimpanzees ate them in both places (Hicks et al. 2019a). North Uele chimpanzees preyed on $D$. wilverthii with tools, and $D$. terrificus appeared in their dung. South Uele chimpanzees used tools to prey on D. terrificus, and we found D. wilverthii in a dung sample (Hicks et al. 2019a). These species are known to be consumed elsewhere (i.e., Kalinzu, Uganda) by chimpanzees using tools (Schöning et al. 2008).

From personal experience, TH can attest that epigaeic Dorylus to the north and south of the Uele were similarly aggressive, swarming rapidly and delivering painful bites upon provocation. We know from remains in dung samples and one tool site that South Uele chimpanzees eat these ants (Hicks et al. 2019a); thus it is unlikely that palatability is an issue. Epigaeic Dorylus holes north of the Uele were significantly deeper than other insect holes we measured (Hicks et al. 2019a), but we lack measurements from south of the Uele for comparison purposes. It is striking that multiple populations of chimpanzees use tools to prey upon multiple species of epigaeic Dorylus in environments ranging from savanna to tropical forest (reviewed in Schöning et al. 2008 and Sanz et al. 2010), and yet for the most part those tools are nowhere near as long as the North Uele ones (Hicks et al. 2019a). As we cannot rule out that some feature as the North Uele ants themselves may promote the use of these long tools, we require more comparative studies of the characteristics of these ants on both sides of the Uele River, in relation to those consumed by chimpanzees elsewhere.

\section{Soil Hardness, Seasonality, Dryness, and Other Ecological and Climatic Factors}

Major differences exist between the habitats north and south of the Uele River, in both seasonality of rainfall (less seasonality further south), soil makeup (more exposed laterite in the northern savannas, possibly more swamp forest to the south), and degree of human disturbance, including hunting, mining, and agriculture (Hicks 2010). Such factors, which are poorly understood in our survey area, may impact the behavior of the chimpanzees, both in terms of the differences between epigaeic Dorylus tool use to the north and south and overarching differences between the chimpanzees of northern DRC and those at other sites in Africa. For instance, differences in soil composition or 
hardness may affect the depth of driver ant holes or the hardness of termite mounds. As an example of the indirect manner in which ecological factors can affect complex chimpanzee behavior, Boesch (1994) argued that a closed canopy forest can lead to the apes developing complex strategies to hunt monkeys, compared to simpler strategies used in forests with more broken cover.

Any such explanation would need to account for the fact that chimpanzees use tools to prey on both driver ants and Macrotermes spp. at multiple sites across Africa with diverse climatic and geological features. Likewise, chimpanzees generally ignore Cubitermites and Thoracotermes spp. at those sites. Perhaps some constellation of features explains the unique distribution of such tool-use and food-processing behaviors across northern DRC. Culture may provide a more parsimonious explanation, but for the moment, lacking comparative studies, we must withhold judgment.

\section{Availability of Plant Species to Construct Tools}

Perhaps differences in the abundance or distribution of raw materials used for tool construction exist across the area, which might explain the differences in epigaeic Dorylus tool use north vs. south of the Uele River. It might be argued that a particular kind of stick that is abundant north of the Uele serves as an excellent raw material for fashioning these long stick probes. This is unlikely, however, as, the four survey regions in which we found no tools (Hicks et al. 2019a) were located in dense lowland forest, which offered abundant saplings. Open, savanna-dominant regions, namely Zapay and Gbangadi, where potentially fewer sticks might be available for tool manufacture, had some of the highest tool encounter rates found, for multiple types of insects, including two epigaiec Dorylus sites at Zapay.

The possibility that a differential availability of plant tool sources might explain our results is undercut by the fact that the North Uele chimpanzees did not depend on any particular plant species to hunt epigaeic Dorylus ants with their long stick probes. Instead, the chimpanzees used a wide diversity of plant species (29) to make those 54 tools (Hicks et al. 2019a). Although our data on plant species availability to the south of the Uele River are incomplete, many of the plants used by the chimpanzees to make epigaeic Dorylus tools to the north were widely available across the area (Table IV; see ESM 4 for a detailed discussion). Of the 16 epigaeic Dorylus tool plant source species from North Uele, 9 were shared between North and South Uele forests (Gérard 1960), and 14 of these also occur in the Ituri Forest far to the east. If we expand sources to include those identified to the genus level, 17 were shared between North and South Uele and 19 occur in Ituri (ESM 4, Table SIV); thus it is unlikely that a difference in occurrence of these plants was a limiting factor for tool use south of the Uele.

In summary, the Bili-Uéré chimpanzees were not obviously limited to using specific plant species to prey on epigaeic Dorylus ants and instead were quite flexible in their choice of materials (Table IV; ESM 4, Table SIII; Hicks et al. 2019a), making it unlikely that the availability of specific plants was a limiting factor for them in constructing their tools. Thus the opportunity hypothesis is not supported by our data. In the future, however, systematic comparisons should be made between densities of these plant species north and south of the Uele and not just presence/absence. 


\section{Diverse Habitat in Northern DRC Makes Ecological Explanations for Distribution of Bili-Uéré Behavioral Realm Unlikely}

Despite the interregional differences in tool use for epigaeic Dorylus ants and a few other behaviors, we see when adopting a pan-African perspective that the behaviors of the northern DRC chimpanzees are surprisingly uniform across a large geographical area (Hicks et al. 2019a). The habitat types to the north and south of the Uele River were quite different: mosaic vs. lowland forest, respectively (Fig. 1), and the climate of North Uele is more seasonal (Hicks 2010). It is thus unlikely that any overarching ecological similarity shared across the two sides of the river might explain the behavioral continuity found in northern DRC chimpanzees. This similarity of behaviors is perhaps surprising given that drier woodland or grassland habitats may exert different physiological or environmental pressures on chimpanzees than wetter, more forested ones (Wessling et al. 2018; Boyer-Ontl and Pruetz, this issue). Without any obvious ecological factor promoting behavioral convergence in the chimpanzees of northern DRC, this relatively uniform set of behaviors (sticks used to prey on ants, termite mound pounding, lack of termite fishing, and ground nesting) may be explained by "cultural override" (Gruber et al. 2009). Given the relatively recent divergence and expansion of Eastern chimpanzees (Lobon et al. 2016) and the interconnectedness of much of their population (Hicks et al. 2014), too little time may have passed to allow the diversification of traditions as a response to new environments. These chimpanzees may have maintained their culture in the face of novel environmental conditions encountered over the past few thousand or tens of thousands of years during range expansion. Alternatively, or additionally, perhaps any cultural innovation has been rapidly drowned out by immigrations between the many interconnected communities, reinforcing conservative traditions (Hicks 2010). Although it is difficult to know how fast or slow nonhuman great ape traditions can take to develop, future research on this large, continuous population, especially when combined with refined knowledge of their evolutionary history, will be informative.

Within this "Behavioral Realm," on opposite sides of the Uele River, we may have detected some regional divergence in tool types used to prey on epigaeic Dorylus, as well as food preferences (Hicks et al. 2019b), despite the interconnectivity of the population as a whole. These possible different tool-use styles and "tastes" may represent incipient behavioral differentiation across a large geographic area within a still-interconnected chimpanzee population. Our findings for epigaeic Dorylus contradict the viewpoint that specific ecological conditions "draw out" chimpanzee tool-use behaviors from an innate ability [i.e., the Tennie et al. (2009) "zone of latent solutions" hypothesis]. Although Koops et al. (2013, 2014) demonstrated convincingly that "opportunity" (i.e., ecological conditions/availability of resources) shapes chimpanzee traditions in much the same way it does for humans, our results for epigaeic Dorylus (but not ponerine ants) are consistent with the view that chimpanzee feeding traditions may, like those of humans, sometimes be constrained by cultural override (Gruber et al. 2009, 2011). Before we can be certain of this, however, we need to know for how long the chimpanzees on both sides of the Uele River have been separated from one another, as they apparently are today in the Bili-Uéré area (Hicks 2010). This knowledge would give us a time frame allowing to track the pace of the differentiation of these possible incipient traditions. We can also ask ourselves whether we are we missing some hidden 
ecological factor that may explain why chimpanzees in the north use more tools (and a different kind of tool) to prey on driver ants. The "necessity hypothesis" may come into play in ways that are difficult to detect (Grund et al. 2019). For example, it could be that a lack of salt in the seasonally drier landscape to the north of the Uele River encourages these apes to focus more on targeting epigaeic Dorylus (Koops et al. 2019). Or perhaps the absence of red colobus monkeys (the preferred chimpanzee prey wherever the two species occur together in Africa) in the north leads to an increased consumption of ants. These are only possibilities, however, and not very likely ones for Bili-Uéré. Given that epigaeic Dorylus are consumed elsewhere both at deep forest sites [i.e., Goualogou (Sanz and Morgan 2007) and Taï (Boesch and Boesch 1990) and savanna ones [i.e., Fongoli (Bogart and Pruetz 2011) and Assirik (Hunt and McGrew 2002)], as well as in forests where chimpanzees are known to hunt red colobus, no simple correlates with ecological conditions seem to exist.

\section{Lack of Tool Use to Acquire Macrotermes Supports the Argument for Cultural Override}

In addition to their apparently limited use of tools to consume aggressive Dorylus in the south, chimpanzees appear to ignore the abundant Macrotermes sp. termites in northern DRC (Hicks et al. 2019a), while these insects are preyed upon with tools by multiple other chimpanzee populations. As they do elsewhere, Macrotermes muelleri termites in northern DRC travel in surface swarms and are edible for humans; our Zande assistants at Bili prized their flavor and foraged for them by hand when we encountered their swarms. We can thus probably exclude the possibility that some unique defensive behavior of these termites explains their apparent absence from the diet of the Bili-Uéré chimpanzees (Hicks et al. 2019a). We cannot, however, rule out that some other unknown difference between this and other populations (i.e., mound hardness or reluctance of soldiers to bite onto probes) may explain this (lack of) behavior. Given that chimpanzees use tools to prey on Macrotermes spp. across a diverse range of habitats in Africa, ranging from savannas (Fongoli: Bogart and Pruetz 2011) to tropical rainforest (Goualougo: Sanz and Morgan 2007) and everything in between (reviewed in McGrew 1992 and Webster et al. 2014), it is perhaps difficult to envisage a salient and all-encompassing difference in northern DRC Macrotermes muelleri that would explain the apparent absence of this insect from the diet of the chimpanzees across a large and ecologically diverse area. This lack of termite-fishing is shared by the Semliki chimpanzees (Webster et al. 2014), where Macrotermes sp. are common. We do not know if the latter absence is connected to the widespread Bili-Uéré tradition. At Bili-Uéré, the behavior appears to be absent not only from lowland forest, but from mosaic as well, making the Semliki savannaassociated "reduced handling time" hypothesis unlikely to apply, at least to the non-moist tropical lowland forest habitat. A similar pattern can be seen regarding the nearly unique termite mound-pounding behavior found across a large area of northern DRC, focused on Cubitermes sp. and Thoracotermes macrothorax (Hicks et al. 2019a). These patterns of behavior are at least consistent with cultural override. 


\section{Conclusions}

Chimpanzee material culture is clearly influenced to some degree by the ecological availability of resources (Koops et al. 2013, 2014). In addition, chimpanzees may, like humans, bring their own cultural preferences and predilections to the table (Gruber et al. 2009; Webster et al. 2014; Whiten 2017, 2019), leading to cultural override. The mismatch between resource availability and tool use that we documented in this article and in Hicks et al. (2019a) is consistent with this hypothesis, although we cannot rule out less obvious ecological influences. On a larger scale, the relative behavioral uniformity of the northern DRC chimpanzees across a wide range of habitats (Hicks et al. 2019a) indicates that these hominids, instead of responding passively to whatever food sources happen to be common around them, may conservatively follow deeply ingrained traditions as to what they regard as food and how they fashion their tools, which differ from those of other well-studied populations of the species. Nevertheless, subtle differences in prey preference and tool construction may indicate a degree of burgeoning behavioral divergence within this area. To speculate, perhaps at Bili-Uéré we are catching the evolution of incipient chimpanzee traditions in the act.

In northern DRC, we have an almost unprecedented opportunity to observe the spread of culture in one of our closest hominid relatives across large geographic distances of interconnected habitat. Such areas are becoming increasingly rare in today's human-dominated landscape. Not only should this motivate us to protect these priceless chimpanzee traditions, but to document them as well, before they are damaged or destroyed by human incursion. A stroke of luck has allowed this population to survive; it is up to us to ensure it does so into the future.

Acknowledgments We thank the Ministère de l'Environnement of the DRC and the Institut Congolais pour la Conservation de la Nature (ICCN) for granting us permission to work in the DRC. Laura Darby-Singh and Adam Darby-Si Singh assisted with the South Uele surveys. Karsten Dierks ran the Pan African Bili-Gangu site and collected data on tools. We thank the following supporters of our project: The Wasmoeth Wildlife Foundation, Lucie Burgers Foundation, International Primate Protection League, African Wildlife Foundation, Le Centre de Rehabilitation des Primates de Lwiro, US Fish and Wildlife Service, Panafrican Programme of the Max Planck Institute for Evolutionary Anthropology, Karl Ammann, Jan Sevink, and Jan van Hooff. We also thank Terese Hart, Mimi Arandjelovic, Mizuki Murai, Claudia Nebel, Andreas Walther, and Rainer Benz. We are grateful for the hard work and knowledge of our field assistants, in particular team leaders Ephrem Mpaka, Henri Silegowa, Gilbert Pakulu, Bebe Bofenda, Ligada Faustin, Chief Mbolibie Cyprian, and Kisangola Polycarpe, as well as Olivier Esokeli, Seba Koya, Dido Makeima, Makassi Constant, Likambo, Likongo, Garavura Roger, and Kongonyesi. Yisa Ginath and Louwtjie Dutoit provided assistance with the maps, and Sonia Uribe helped to make the figures. Volker Sommer, Alejandra Pascual-Garrido, Lydia Luncz, Jan van Hoff, and Carel van Schaik, as well as Jo Setchell and two anonymous reviewers also provided useful suggestions and feedback.

Authors' Contributions TH conceived the research, collected the data, led the Bili-Uéré survey missions and wrote the manuscript. PR and RM also contributed to writing the manuscript.

Statistical analyses, maps and figures: RM, TH and PR.

Research protocol design: TH, HK, JH, CB, RM and SM.

Comments on the manuscript: PR, JH, HK, CB, RM, CE, SM.

Funding This work has been developed within the project "A survey of Chimpanzee Material Culture in Eastern DR Congo" financed by the National Science Center, Poland on the basis of the Decision no. DEC2017/25/B/NZ8/02730. 
Open Access This article is licensed under a Creative Commons Attribution 4.0 International License, which permits use, sharing, adaptation, distribution and reproduction in any medium or format, as long as you give appropriate credit to the original author(s) and the source, provide a link to the Creative Commons licence, and indicate if changes were made. The images or other third party material in this article are included in the article's Creative Commons licence, unless indicated otherwise in a credit line to the material. If material is not included in the article's Creative Commons licence and your intended use is not permitted by statutory regulation or exceeds the permitted use, you will need to obtain permission directly from the copyright holder. To view a copy of this licence, visit http://creativecommons.org/licenses/by/4.0/.

\section{References}

Boesch, C. (1994). Chimpanzees-red colobus monkeys: A predator-prey system. Animal Behaviour, 47(5), 1135-1148.

Boesch, C. (2012). Wild cultures: A comparison between chimpanzee and human cultures. Cambridge: Cambridge University Press.

Boesch, C., \& Boesch, H. (1990). Tool use and tool making in wild chimpanzees. Folia Primatologica, 54(12), 86-99.

Boesch, C., Gonê Bi, Z. B., Anderson, D. P., \& Stahl, D. (2006). Food choice in Taï chimpanzees: Are cultural differences present? In G. Hohmann, M. Robbins, \& C. Boesch (Eds.), Feeding ecology in apes and other primates (pp. 365-399). Cambridge: Cambridge University Press.

Bogart, S. L., \& Pruetz, J. D. (2011). Insectivory of savanna chimpanzees (Pan troglodytes verus) at Fongoli, Senegal. American Journal of Physical Anthropology, 145(1), 11-20.

Burgess, N., Hales, J. D.’. A., Underwood, E. C., \& Dinerstein, E. (2004). Terrestrial ecoregions of Africa and Madagascar: A conservation assessment (p. 245). Gland, Switzerland: World Wildlife Fund.

Collins, D. A., \& McGrew, W. C. (1987). Termite fauna related to differences in tool-use between groups of chimpanzees (Pan troglodytes). Primates, 28(4), 457-471.

Falótico, T., Spagnoletti, N., Haslam, M., Luncz, L. V., Malaivijitnond, S., \& Gumert, M. (2017). Analysis of sea almond (Terminalia catappa) cracking sites used by wild Burmese long-tailed macaques (Macaca fascicularis aurea). American Journal of Primatology, 79, e22629.

Field, A. (2005). Discovering statistics using SPSS. London: SAGE.

Fünfstück, T., Arandjelovic, M., Morgan, D. B., Sanz, C., Reed, P., et al (2015). The sampling scheme matters: Pan troglodytes troglodytes and P. t. schweinfurthii are characterized by clinal genetic variation rather than a strong subspecies break. American Journal of Physical Anthropology, 156(2), 181-191.

Gagneux, P., Gonder, M., Goldberg, T., \& Morin, P. (2001). Gene flow in wild chimpanzee populations: What genetic data tell us about chimpanzee movement over space and time. Philosophical Transcripts of the Royal Society of London, 356, 889-897.

Ganas, J., \& Robbins, M. M. (2004). Intrapopulation differences in ant eating in the mountain gorillas of Bwindi Impenetrable National Park, Uganda. Primates, 45(4), 275-278.

Ganas, J., Robbins, M. M., Nkurunungi, J. B., Kaplin, B. A., \& McNeilage, A. (2004). Dietary variability of mountain gorillas in Bwindi impenetrable National Park, Uganda. International Journal of Primatology, 25(5), 1043-1072.

Gérard, P. (1960). Étude écologique de la forêt dense à Gilbertiodendron dewevrei dans la région de l'Uele (No. 87). Institut national pour l'étude agronomique du Congo.

Gruber, T., Muller, M. N., Strimling, P., Wrangham, R., \& Zuberbühler, K. (2009). Wild chimpanzees rely on cultural knowledge to solve an experimental honey acquisition task. Current Biology, 19(21), 1806-1810.

Gruber, T., Muller, M., Reynolds, V., Wrangham, R. W., \& Zuberbühler, K. (2011). Community-specific evaluation of tool affordances in wild chimpanzees. Scientific Reports, 1, 128.

Gruber, T., Zuberbühler, K., \& Neumann, C. (2016). Travel fosters tool use in wild chimpanzees. eLife, 5, e16371.

Grund, C., Neumann, C., Zuberbühler, K., \& Gruber, T. (2019). Necessity creates opportunities for chimpanzee tool use. Behavioral Ecology, 30(4), 1136-1134. https://doi.org/10.1093/beheco/arz062.

Haun, D. B. M., Rapold, C. J., Call, J., Janzen, G., \& Levinson, S. C. (2006). Cognitive cladistics and cultural override in Hominid spatial cognition. Proceedings of the National Academy of Sciences of the USA, 103, $17568-17573$.

Haun, D. B., Rekers, Y., \& Tomasello, M. (2014). Children conform to the behavior of peers; other great apes stick with what they know. Psychological Science, 25(12), 2160-2167. 
Hicks, T. C. (2010). A chimpanzee mega-culture? Exploring behavioral continuity in Pan troglodytes schweinfurthii across northern DR Congo. PhD thesis, University of Amsterdam.

Hicks, T. C., Darby, L., Hart, J., Swinkels, J., January, N., \& Menken, S. (2010). Trade in orphans and bushmeat threatens one of the Democratic Republic of the Congo's most important populations of Eastern Chimpanzees (Pan troglodytes schweinfurthii). African Primates, 7(1), 1-18.

Hicks, C., Roessingh, P., \& Menken, S. B. J. (2013). Impact of humans on long-distance communication behaviour of eastern chimpanzees (Pan troglodytes schweinfurthii) in the Northern Democratic Republic of the Congo. Folia primatologica, 84(3-5), 135-156.

Hicks, T. C., Tranquilli, S., Kühl, H. S., Campbell, G., Swinkels, J., et al (2014). Absence of evidence is not evidence of absence: Discovery of a large, continuous population of Pan troglodytes schweinfurthii in the Central Uele region of northern DRC. Biological Conservation, 171, 107-113.

Hicks, T. C., Kühl, H. S., Boesch, C., Dieguez, P., Ayimisin, A. E., et al. (2019a). Bili-Uéré: A chimpanzee behavioural realm in Northern DR Congo. Folia Primatologica, 90(1), 3-64. Additional data can be found here: https://figshare.com/articles/Hicks et al 2019 Additional Data docx Additional Data relating to_Hicks_et al 2019 Bili-Uéré_A chimpanzee behavioral realm in DR_Congo_/7441277

Hicks, T. C., Menken, S. B. J., Laudisoit, A., \& Hart, J. (2019b). Handling and consumption of vertebrate prey by chimpanzees (Pan troglodytes schweinfurthii) in the Northern Democratic Republic of the Congo. In M. L. Jensvold (Ed.), Chimpanzee behavior: Recent understandings from captivity and the forest. Hauppauge, NY: Nova Science Publishers.

Hobaiter, C., Samuni, L., Mullins, C., Akankwasa, W. J., \& Zuberbühler, K. (2017). Variation in Hunting behaviour in neighbouring chimpanzee communities in the Budongo forest, Uganda. PloS ONE, 12(6), e0178065.

Hunt, K. D., \& McGrew, W. C. (2002). Chimpanzees in the dry habitats of Assirik, Senegal and Semliki wildlife reserve. Uganda. Behavioural Diversity in Chimpanzees and Bonobos, 35-51.

Jaeggi, A. V., Dunkel, L. P., van Noordwijk, M. A., Wich, S. A., Sura, A. A. L., \& van Schaik, C. P. (2010). Social learning of diet and foraging skills by wild immature Bornean orangutans: Implications for culture. American Journal of Primatology, 72, 62-71.

Koops, K., McGrew, W. C., \& Matsuzawa, T. (2013). Ecology of culture: Do environmental factors influence foraging tool use in wild chimpanzees, Pan troglodytes verus? Animal Behaviour, 85(1), 175-185.

Koops, K., Visalberghi, E., \& van Schaik, C. (2014). The ecology of primate material culture. Biology Letters, 10(11), 20140508.

Koops, K., Wrangham, R. W., Cumberlidge, N., Fitzgerald, M. A., van Leeuwen, K. L., et al (2019). Crabfishing by chimpanzees in the Nimba Mountains. Guinea. Journal of Human Evolution. https://doi.org/ 10.1016/j.jhevol.2019.05.002.

Krebs, J. R. (2009). The gourmet ape: Evolution and human food preferences. The American Journal of Clinical Nutrition, 90(3), 707S-711S.

Langergraber, K., Boesch, C., Inoue, E., Inoue-Murayama, M., Mitani, J., et al (2010). Genetic and 'cultural' similarity in wild chimpanzees. Proceedings of the Royal Society B: Biological Sciences, 278(1704), 408416.

Lisingo, J. L. (2016). Organisation spatiale de la diversité spécifique d'arbres en forêt tropicale dans le bassin nord-est de la Cuvette Centrale Congolaise. PhD thesis, University of Kisangani.

Lobon, I., Tucci, S., de Manuel, M., Ghirotto, S., \& Benazzo, A. (2016). Demographic history of the genus Pan inferred from whole mitochondrial genome reconstructions. Genome Biology and Evolution, 8(6), 2020-2030.

Luncz, L. V., \& Boesch, C. (2015). The extent of cultural variation between adjacent chimpanzee (Pan troglodytes verus) communities: A microecological approach. American Journal of Physical Anthropology, 156(1), 67-75.

Luncz, L. V., Wittig, R. M., \& Boesch, C. (2015). Primate archaeology reveals cultural transmission in wild chimpanzees (Pan troglodytes verus). Philosophical Transactions of the Royal Society B: Biological Sciences, 370, 20140348.

Makana, J.-R., Hart, T. B., Ewango, C. E. N., Liengola, I., Hart, J. A., \& Condit, R. (2004). Ituri Forest dynamics plots, DRC. In Tropical forest diversity and dynamism: Findings from a large-scale plot network (pp. 492-505). Chicago: University of Chicago Press.

Marshall-Pescini, S., \& Whiten, A. (2008a). Social learning of nut-cracking behaviour in East African sanctuary-living chimpanzees (Pan troglodytes schweinfurthii). Journal of Comparative Psychology, 122, 186-194.

Marshall-Pescini, S., \& Whiten, A. (2008b). Chimpanzees (Pan troglodytes) and the question of cumulative culture: An experimental approach. Animal Cognition, 11(3), 449-456.

McCullagh, P., \& Nelder, J. A. (1998). Generalized linear models. London: Chapman and Hall. 
McGrew, W. C. (1992). Chimpanzee material culture: Implications for human evolution. Cambridge: Cambridge University Press.

McGrew, W. C. (2004). The cultured chimpanzee: Reflections on cultural primatology. Cambridge: Cambridge University Press.

McGrew, W. C., \& Tutin, C. E. (1978). Evidence for a social custom in wild chimpanzees? Man, 13, 234 251.

Möbius, Y., Boesch, C., Koops, K., Matsuzawa, T., \& Humle, T. (2008). Cultural differences in army ant predation by West African chimpanzees? A comparative study of microecological variables. Animal Behaviour, 76(1), 37-45.

Murdock, G. P. (1981). Atlas of world cultures. Pittsburgh: University of Pittsburgh Press.

Nakamura, M. (2002). Grooming-hand-clasp in Mahale M group chimpanzees: Implications for culture in social behaviours. In C. Boesch, G. Hohmann, \& L. Marchant (Eds.), Behavioural diversity in chimpanzees and bonobos (pp. 71-83). Cambridge: Cambridge University Press.

Ndiaye, P. I., Badji, L., Lindshield, S. M., \& Pruetz, J. D. (2018). Nest-building behaviour by Chimpanzees (Pan troglodytes verus) in the non-protected area of Diaguiri (Kedougou, Senegal): Implications for conservation. Folia Primatologica, 89, 316-326.

Nishida, T., Wrangham, R. W., Goodall, J., \& Uehara, S. (1983). Local differences in plant-feeding habits of chimpanzees between the Mahale Mountains and Gombe National Park, Tanzania. Journal of Human Evolution, 12(5), 467-480.

Panger, M. A., Perry, S., Rose, L., Gros Louis, J., Vogel, E., et al (2002). Cross-site differences in foraging behavior of white-faced capuchins (Cebus capucinus). American Journal of Physical Anthropology, $119(1), 52-66$.

Pennec, F., Gérard, C., Meterreau, L., Monghiemo, C., Bokika Ngawolo, J. C., Laurent, R., Narat, V. (2020). Spatio-temporal variation of bonobo (Pan paniscus) habitat use in a forest-savanna mosaic. International Journal of Primatology. (this issue).

R Core Team (2018). R: A Language and Environment for Statistical Computing. Vienna, Austria: R Foundation for Statistical Computing.

Robbins, M. M., Ando, C., Fawcett, K. A., Gruiter, C. C., Hedwig, D., et al (2016). Behavioural variation in gorillas: Evidence of potential cultural traits. PLOS ONE, 11, e0160483.

Sanz, C. M., \& Morgan, D. B. (2007). Chimpanzee tool technology in the Goualougo Triangle, Republic of Congo. Journal of Human Evolution, 52(4), 420-433.

Sanz CM, Schoning C, Morgan DB (2010). Chimpanzees prey on army ants with specialized tool set. American Journal of Primatology, 72, 17-24.

Scholliers, P. (2001). Food, drink and identity. Oxford: Berg.

Schöning, C., Humle, T., Möbius, Y., \& McGrew, W. C. (2008). The nature of culture: technological variation in chimpanzee predation on army ants revisited. Journal of Human Evolution, 55(1), 48-59.

Stewart, F. (2011). The evolution of shelter: Ecology and ethology of chimpanzee nest building. Doctoral dissertation, University of Cambridge.

Tennie, C., Call, J., \& Tomasello, M. (2009). Ratcheting up the ratchet: On the evolution of cumulative culture. Philosophical Transactions of the Royal Society B: Biological Sciences., 364(1528), 2405-2415.

van Leeuwen, K., Hill, R., Korstjens, A. (2020) Quantifying chimpanzee (Pan troglodytes) landscapes: An environmental approach to classifying forest and savanna chimpanzees. International Journal of Primatology. (this issue).

Venables, W. N., \& Ripley, B. D. (2002). Modern applied statistics with S (4th ed.). New York: Springer Science+Business Media.

Watson, S. K., Lambeth, S. P., Schapiro, S. J., \& Whiten, A. (2018). Chimpanzees prioritise social information over existing behaviours in a group context but not in dyads. Animal Cognition, 21, 407-418.

Webster, T. H., McGrew, W. C., Marchant, L. F., Payne, C. L., \& Hunt, K. D. (2014). Selective insectivory at Toro-Semliki, Uganda: Comparative analyses suggest no 'savanna'chimpanzee pattern. Journal of Human Evolution, 71, 20-27.

Wessling, E. G., Deschner, T., Mundry, R., Pruetz, J. D., Wittig, R. M., \& Kühl, H. S. (2018). Seasonal variation in physiology challenges the notion of chimpanzees (Pan troglodytes verus) as a forest-adapted species. Frontiers in Ecology and Evolution, 6(60), 1-21.

Whiten, A. (2017). How culture extends the scope of evolutionary biology in the great apes. Proceedings of the National Academy of Sciences of the USA, 114, 7790-7797.

Whiten, A. (2019). Conformity and over-imitation: An integrative review of variant forms of hyper-reliance on social learning. Advances in the Study of Behavior, 51, 31-75.

Whiten, A., Goodall, J., McGrew, W. C., Nishida, T., Reynolds, V., et al (1999). Cultures in chimpanzees. Nature, 399(6737), 682-685. 
Whiten, A., Horner, V., \& De Waal, F. B. M. (2005). Conformity to cultural norms of tool use in chimpanzees. Nature, 437(7059), 737.

World Wildlife Fund (Content Partner); Mark McGinley (Topic Editor) (2007). Northern Congolian forestsavanna mosaic. In C. J. Cleveland (Ed.), Encyclopedia of earth. Washington, DC: Environmental Information Coalition, National Council for Science and the Environment. [Published in the Encyclopedia of Earth March 21, 2007; Retrieved November 27, 2009]. https://editors.eol.org/eoearth/ wiki/Northern_Congolian_forest-savanna_mosaic.

Yamakoshi, G. (1998). Dietary responses to fruit scarcity of wild chimpanzees at Bossou, Guinea: Possible implications for ecological importance of tool use. American Journal of Physical Anthropology, 106(3), 283-295.

\section{Affiliations}

Thurston C. Hicks ${ }^{1,2} \cdot$ Hjalmar S. Kühl ${ }^{2,3} \cdot$ Christophe Boesch $^{2} \cdot$ Steph B. J. Menken $^{4} \cdot$ John Hart $^{5} \cdot$ Peter Roessingh $^{4} \cdot$ Corneille Ewango $^{6} \cdot$ Roger Mundry $^{7}$

1 The Faculty of "Artes Liberales", University of Warsaw, Warsaw, Poland

2 Max Planck Institute for Evolutionary Anthropology, Department of Primatology, Leipzig, Germany

3 German Centre for Integrative Biodiversity Research Halle-Jena-Leipzig, Leipzig, Germany

4 Institute for Biodiversity and Ecosystem Dynamics, University of Amsterdam, Amsterdam, The Netherlands

5 Lukuru Wildlife Research Foundation, Kinshasa, Democratic Republic of Congo

6 The University of Kisangani, Faculty of Renewable Natural Resources Management (FGRNR/FRNRM)/ Faculty of Sciences (FSc), Kisangani, Democratic Republic of Congo

7 Max Planck Institute for Evolutionary Anthropology, Leipzig, Germany 